\title{
Sports Rights and the Broadcast Industry
}

\author{
Martin Cave* \\ Brunel University
}

Robert W. Crandall

The Brookings Institution

\section{Introduction}

The increasing popularity of televised sports events in the U.S. and Europe has had significant effects on the broadcasting sectors and sports leagues on both sides of the Atlantic. As a result, competition authorities have shown considerable interest in the evolution of sports broadcast rights on both continents. In the U.S., attention has been focused on professional and amateur (intercollegiate) leagues alike, while in Europe most attention has been given to the relationship between broadcasting and various countries' professional soccer leagues. The recent attempt by the UK's leading pay-television operator, BSkyB, to purchase the leading soccer club, Manchester United, has changed the tone if not the substance of broadcast sports rights negotiations in the UK and, perhaps, throughout Europe.

This paper focuses upon the competition and efficiency issues involved in the granting of broadcast rights by sports teams or leagues and their resolution on both sides of the Atlantic. What are the consequences of collective (and exclusive) selling by sports leagues of their

\footnotetext{
${ }^{*}$ Cave is grateful for helpful comments to Campbell Cowie and Stefan Szymanski.
} 
broadcast rights? Does the control of sports broadcast rights allow the broadcaster to leverage its position and increase its monopoly power? Can leagues foreclose entry by competitors through widespread sale of broadcast rights to local or national broadcaste rs? Can ownership of sports teams by broadcasters have anti-competitive effects? Although we do not offer any new insights on these well-researched theoretical issues, we provide evidence to suggest that such problems are much less acute in the United States than in Europe.

We begin with a discussion of the evolution of sports leagues in the U.S. and Europe. We then turn to the changing structure of broadcasting on both sides of the Atlantic.

Finally, we analyse the changes in the structure of sports broadcast rights and their likely effect on league balance, league monopoly power, and market power in broadcasting.

\section{The Sports Marketplace}

\section{Sports in the United States}

The United States has a much more diverse set of sports leagues available for broadcasting than any other part of the world. There are major professional sports leagues for baseball, football, basketball and hockey which have been in existence for decades and which have lucrative broadcasting contracts with various commercial broadcast networks, local broadcast stations, direct broadcast satellite services, and cable networks. In addition, college basketball, college football, professional soccer, professional golf, professional tennis, and automobile racing enjoy wide broadcast exposure.

The bargaining power of the seller of sports broadcast rights depends in part on the number of alternative sources of such programming that are available. In the United States, each of the major professional sports is organized as a single league. The National Football League (NFL), Major League Baseball (MLB), the National Basketball Association (NBA), and the National Hockey League (NHL) currently have no professional competitors in their respective 
sports. These dominant positions have existed for at least two decades. Although entry by new leagues had been quite common in earlier decades, only one new league has been formed in the past twenty years.

Major League Baseball has been immune from serious competitive entry threats since World War I. The other professional sports leagues-basketball, football, and hockey-had substantial new competition in the 1960s and 1970s before the liberalization of U.S. broadcast-cable policy, but none since then. The American Basketball Association was formed in 1967 and lasted until 1976 when it began to fail as three of its nine teams suspended operations. A fourth team failed at the end of the season, and four of the remaining teams were simply absorbed into the incumbent NBA league. A rival football league, the American Football League, was formed to challenge the NFL in 1960, but it reached a merger agreement with the NFL in 1966 and was fully absorbed into the NFL by 1970. Two subsequent entrants, the World Football League (1974-75) and the USFL (1983-85), were much less serious competitive threats to the NFL, and both quietly folded without any of their teams being absorbed by the NFL. Finally, in hockey, the World Hockey League, mounted a serious challenge to the $\mathrm{NHL}$ in $1972-79$, but it finally succumbed with only four of its remaining seven teams being absorbed by the $\mathrm{NHL}$.

The apparent reasons for this recent lack of entry are (i) the continual expansion of the incumbent leagues, (ii) the evolution of players' negotiating power over salaries, and (iii) the pre-emption of broadcast opportunities through expansion of television coverage by the incumbent leagues. We deal with the first two of these briefly in this section, leaving the discussion of broadcast coverage to a later section. ${ }^{1}$

First, the United States has witnessed substantial population growth and western expansion. Had the major sports leagues failed to expand from their original limited eastern and

\footnotetext{
${ }^{1}$ There are numerous sources of information on each of these topics. See, for example, Quirk and Fort (1992); Scully (1995); and Sheehan (1996).
} 
midwestern locations, new leagues would surely have exploited this failure. Baseball was the first to move west and to expand. Between 1903 and 1950, there was no change in the identity of MLB's teams. The southern and western limits of baseball were defined by two of the league's 16 teams that were located in St. Louis. Beginning in 1958, however, major-league baseball shifted strongly westward and southward. Today, baseball has 30 teams, 15 of which are as south or west of St. Louis. In most of the new cities, local and state tax monies have been mobilized to pay for stadiums that are leased exclusively to MLB teams during baseball season. Thus, the ability of a new league to exploit new geographic markets has been substantially preempted. ${ }^{2}$ Similarly, football, hockey and basketball have expanded dramatically since 1960, with hockey's expansion being the most dramatic. In 1960, the NHL had but six teams, four of which were in the U.S.; today, the NHL is comprised of 27 teams. (See Table 1.)

Most large metropolitan areas in the U.S. are now blanketed with a baseball, football, hockey, and basketball teams. Hockey, a winter sport, is available in the Arizona desert.

Table 1

The Expansion of U.S. Sports Leagues, 1960-99

\begin{tabular}{|l|c|c|}
\hline League & Number of Teams, 1960 & Number of Teams, 1999 \\
\hline Major League Baseball & 16 & 30 \\
\hline National Football League & 13 & 31 \\
\hline National Basketball Assn. & 8 & 29 \\
\hline
\end{tabular}

${ }^{2}$ It is not surprising that discussions of a new league in North America generally involve consideration of entry opportunities in Mexico. 


\begin{tabular}{|l|l|l|}
\hline National Hockey League & 6 & 27 \\
\hline
\end{tabular}

Basketball, a sport most popular in U.S. inner cities, is even available on the west coast of Canada. Much of this geographical expansion has clearly been motivated by the desire to preempt entry or to absorb teams from the new leagues which formed in the 1960s and 1970s. Had basketball, football, and hockey expanded sooner, they may have foreclosed even these entry attempts.

Second, a protracted set of legal battles has substantially liberalized the player market, allowing players in each league to achieve "free-agent" status after a number of years. The result has been a remarkable escalation of player salaries. According to Quirk and Fort (1992), average real baseball and professional basketball salaries rose nine-fold between 1960 and 1991 while real football salaries increased by nearly 400 percent over the same period. In earlier years, there were numerous player legal challenges to the monopsony power of their teams under league rules. ${ }^{3}$ Until these rules were changed through the institution of player free agency, players could be lured to a new league when dissatisfied. In the past two decades, however, most of the successful, star players have been accommodated to a degree that makes new leagues less attractive to them.

Free agency may not eliminate the monopoly profits from owning a franchise, but it certainly reduces them somewhat, thereby making competitive entry less attractive. Free agency also lowers the probability of competitive entry by reducing the incentives for the most important "star" players to shift to a new league. Without these star players, a new league's prospects for survival are dramatically reduced.

\footnotetext{
${ }^{3}$ The most important of these was Flood v Kuhn, 407 U.S. 258 (1972), a suit brought by Curt Flood, a star player, against MLB, challenging baseball's "reserve" clause that limited players' rights to choose their team and, therefore, to shop for competitive salaries. Similar challenges were mounted by Oscar Robertson against the NBA and John Mackey against the NFL.
} 
Of equal importance, however, has been the ability of the U.S. professional sportsleagues to adapt to increasing numbers of broadcast outlets by expanding the scope of their broadcast coverage. This has occurred both across the domain of off-air networks and cable networks. We return to this phenomenon below.

\section{European Soccer.}

The population of Europe exhibits differentiated tastes for participating in sports and watching them either as spectators or viewers. In the larger countries professional soccer stands out as the most commercialised sport with the most valuable rights, and the discussion below focuses upon it. 4

Professional sports leagues in Europe, such as the English Football League, have been under the control of governing bodies which also administer amateur activities. Sports leagues have traditionally been organised on a hierarchical basis, with promotion and relegation between upper and lower divisions at the end of each season. An entrepreneur or firm can thus enter the business by acquiring an existing club and - if necessary - investing in promotion, rather than by acquiring new franchises. These arrangements make the creation de novo of a competing league at the national level less likely than in the U.S.

Increasing revenues for soccer clubs, many of them derived from broadcasting rights, have, however, encouraged the leading clubs in the UK to seek greater independence within the national association. UK teams had played in a Football League, which has operated under the auspices of the Football Association (F.A.) since 1888. Clubs were normally limited companies, closely held by a small number of shareholders. The League imposed a maximum wage on players until 1961.

4 Formula 1 motor racing is another highly commercialised sport and in 2000 the European Commission was continuing an enquiry into how its television rights were sold. 
In 1992, clubs in the first division of the Football League agreed to form a new competition, the Premier League, directly under the control of the F.A. This enabled them to escape from the majority control of the smaller clubs in the League, and in particular to control directly the sale of broadcast rights and the distribution of associated revenues. Seven years following the formation of the Premier League, 10 of 20 Premier League clubs have floated on the stock market.

UK Premier League soccer clubs enjoyed an increase in turnover between 1991/2 and 1997/8 of 250 percent, making the Premier League the largest in Europe, with an income in 1997/8 three times that of the French league and 42 percent greater than that of Serie A in Italy. (Deloitte and Touche 1999, p 62). The revenues and wage bills of the leading clubs in each of 5 countries are shown in Table 2. The UK clubs' income comes from broadcast revenue (27\%), match-day revenue (36\%) and commercial and other revenue (37\%).

Table 2

Financial Data of Leading European Clubs

\begin{tabular}{|c|c|c|c|c|}
\hline Country & Club & Year & $\begin{array}{c}\text { Revenue } \\
\mathbf{( \$ \mathbf { m } )}\end{array}$ & $\begin{array}{c}\text { Wage Bill } \\
\mathbf{( \$ \mathbf { m } )}\end{array}$ \\
\hline England & $\begin{array}{c}\text { Manchester } \\
\text { United }\end{array}$ & 1997 & 139.4 & 35.8 \\
\hline France & $\begin{array}{c}\text { Paris St. } \\
\text { Germain }\end{array}$ & 1996 & 45.0 & 19.2 \\
\hline Germany & $\begin{array}{c}\text { Bayer } \\
\text { München }\end{array}$ & $\mathrm{n} / \mathrm{a}$ & 90.4 & 20.8 \\
\hline Italy & Juventus & 1997 & 82.3 & 46.2 \\
\hline Spain & Barcelona & 1996 & 65.5 & 27.8 \\
\hline
\end{tabular}

Source: Hoehn and Szymanski (1999) p 209

If the formation of the Premier League was driven by the desire of the top clubs to avoid 
sharing power and broadcasting revenues with inferior clubs, the proposal in 1998 to establish a separate Super League outside the existing framework of competitions involving a fixed group of the best European clubs would have had greater repercussions. Hoehn and Szymanski (1999) argue, however, that such a trend is inevitable, as participation by some clubs in supra-national competitions both widens the dispersion of national clubs' earnings and reduces the incentive to redistribute income in order to maintain competitive balance at the national level. A closed Super League is thus the economic equilibrium.

\section{The Television Marketplace}

\section{The Structure of the U.S. Video Market}

For more than thirty years, the U.S. television industry was highly concentrated as a result of the explicit spectrum-allocation and cable-television policies of the Federal Communications Commission (FCC). The FCC protected a stable three-network off-air oligopoly from various sources of competition on the dubious premise that such protection would encourage entry into the upper UHF band. By the late 1970s, this policy had been exposed as futile, and the Commission—prodded by the courts—responded by easing rules on cable television signal carriage. As a result, cable subscriptions trebled between 1980 and 1990. The 1990s witnessed new entry into direct-to-home (DTH) satellite broadcasting with the development of high-powered satellites and small household receiving dishes. The result of this expansion of cable television and DTH satellite service has been a much more competitive U.S. multichannel video program distribution (MVPD) market.

Until the late 1970s, three commercial networks dominated programming decisions during prime viewing hours, including those involving national sports rights, because of the FCC's policy. ${ }^{5}$ Competition for local broadcast rights might be more intensive in the few markets that had 4 or more commercial VHF stations, but there were only three bidders for national

\footnotetext{
${ }^{5}$ See Owen and Wildman (1992) for a discussion of FCC broadcast policy.
} 
programming, including sports.

National broadcasts of sports leagues were relatively limited prior to 1962. Major league Baseball had a "game of the week" national contract, and the new football entrant, the AFL, had a $\$ 2$ million per-year contract with ABC in 1960-65, but the NFL had been barred by a federal antitrust case from pooling its television broadcast rights into a single national contract. In 1961, however, the Congress passed the Sports Broadcasting Act, which essentially reversed this court decision and allowed league-wide sales of national broadcast rights. The result was a dramatic increase in the value of national network television sports rights throughout the 1960s as a network triopoly bid aggressively for the right to broadcast NFL games, and-more modestly—the rights to other professional league broadcasts. (See Figure 1.)

The liberalization of cable television in $1977-79$ by court decisions and relaxed FCC regulation, combined with the new technology of high-powered direct-to-home satellite distribution, presented the first challenge to the national broadcast triopoly and the first opportunity for national sports leagues to benefit from increased competition for their

\section{Figure 1}




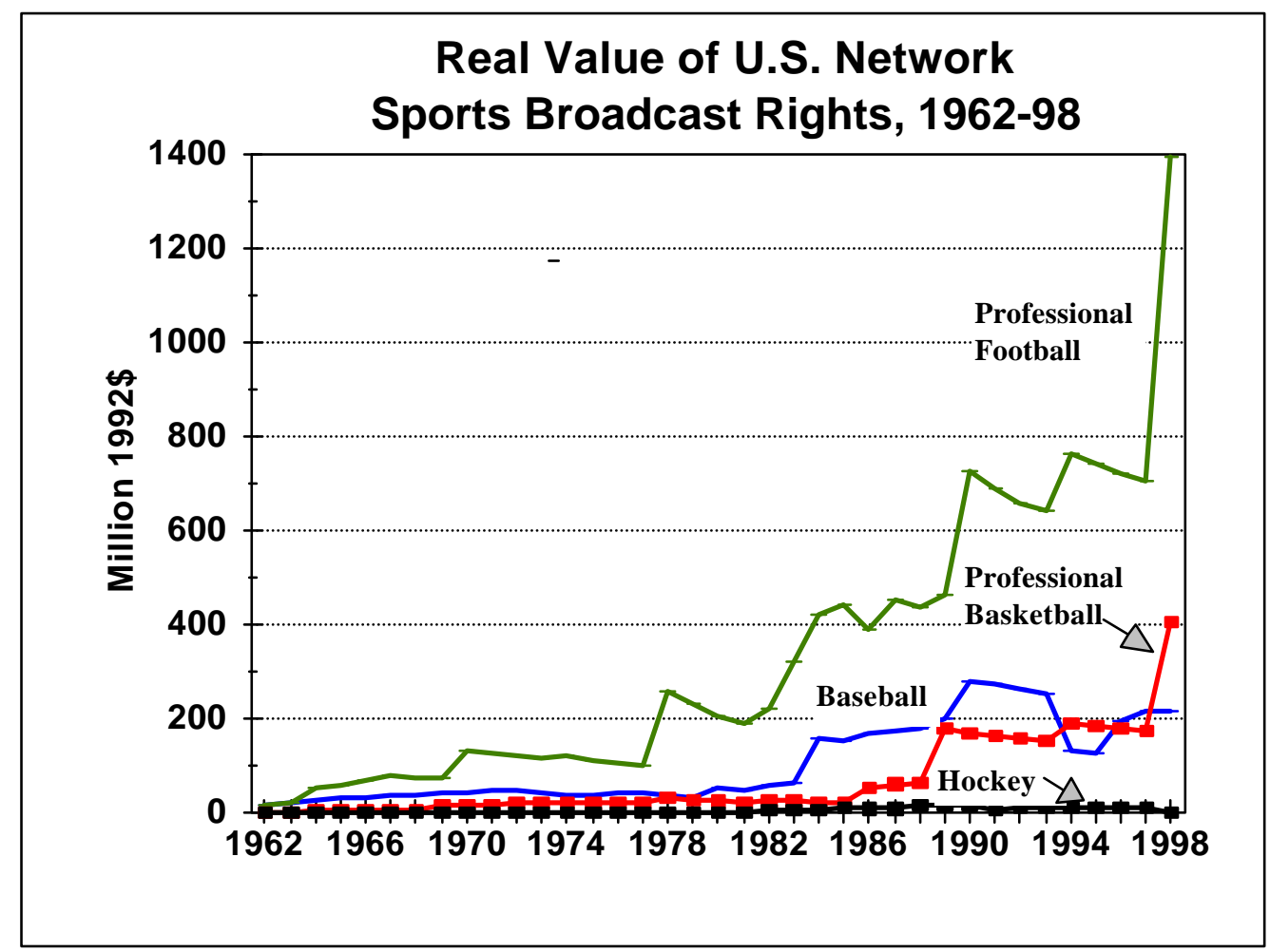

Source: Quirk and Fort (1992); Kagan (1998)

broadcast rights. As Figure 2 shows, there was a modest jump in the real, inflation-adjusted value of national professional sports television rights in 1978, perhaps in response to this developing threat. It was not until 1982-87, however, that a new cable network -

ESPN—actually secured broadcast rights to amajor sports league's games. The total value of sports rights thus increased once again in the 1982-85 period.

The entry of a fourth off-air network, Fox, into the market for national sports rights boosted the value of these rights once again. In 1994, Fox outbid CBS for a portion of the NFL national contract, thereby escalating the competition to four national broadcast networks and the one large cable network. When the 1994-97 contracts expired, CBS re-entered the bidding, and the value of NFL broadcast rights essentially doubled. At about the same time, Fox also bid 


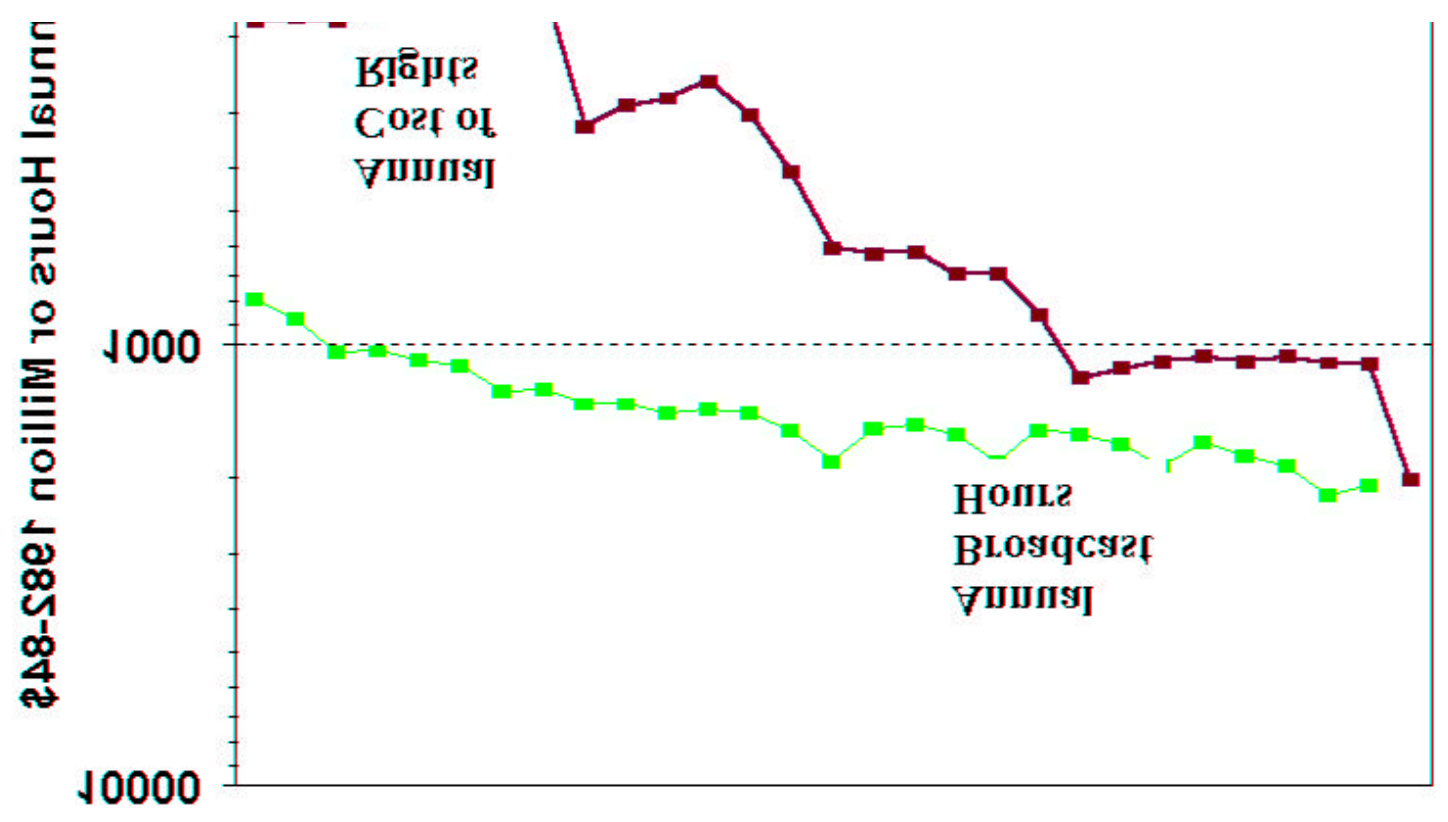

away a large share of the national Major League Baseball contract from $A B C$, but the real value of baseball's broadcast rights remained relatively stable. However, with cable networks in the bidding for NBA broadcast rights, the real value of NBA rights more than doubled in 1997, a reflection of increased media competition and the rising popularity of professional basketball.

Source: Quirk and Fort (1992); Kagan (1998).

In the past five years, another source of competition for broadcasters and cable networks has emerged in the form of high-powered direct broadcast satellite - "direct to home"-satellite broadcasting. DirecTV entered with a new high-powered service in 1993 and EchoStar (DISH Network) followed in 1996. These two companies have slowly built their subscriber bases to 6.5 million and 3.5 million, respectively, but their growth has been hampered by regulations and copyright provisions that limit their ability to retransmit local broadcast signals in areas 
where subscribers can receive these broadcasts off air. Nevertheless, DirecTV is a particularly important bidder for national sports rights, and has succeeded in obtaining the national rights to NFL, MLB, NHL, and NBA games. DISH's sports programming is more limited, confined largely to an offering of 22 regional cable networks, a golf channel, and the English Premier League.

\section{Television Markets in the UK}

Television programming is now delivered in the UK on terrestrial, satelliteand cable platforms. Free-to-air services are transmitted in both digital and analogue form by the BBC (funded by a licence fee) and three advertiser-supported channels. In late 19992.3 million subscribers received satellite pay-TV services in analogue form from BSkyB, and 1.3 million in digital form. (The company intends to transfer all its analogue subscribers to digital by 2001.) In addition 3.1 million households received pay television services in analogue form on cable, which is now dominated by two providers. A roll-out of digital cable services began in late 1999 in some areas. Digital terrestrial transmission (DTT) pay services attracted 0.4 million subscribers. (Competition Commission 2000, p 73).

Pay TV channels comprise basic channels (normally bought in bundled form and representing a channel by channel unraveling of the threads found in free to air services, such as news, comedy, travel, general entertainment, etc.) and premium channels - sports and movies available on an àla carte basis to households subscribing to a basic package. In addition to sports programming available on free-to-air television, pay TV subscribers can generally purchase a sports channel (Eurosport) as part of a basic package and up to three premium sports channels (Sky Sports 1-3).

Audience shares of the five main free-to-air channels and of pay TV services are shown in Table 3, both for all households and for cable and satellite TV households 
Table 3

Share of Viewing by Channel(Second Quarter 1999)

\begin{tabular}{|l|c|c|}
\hline & All Homes & $\begin{array}{c}\text { Satellite TV } \\
\text { Homes }\end{array}$ \\
\hline BBC 1 \& & 39.7 & 27.3 \\
\hline ITV & 30.7 & 24.1 \\
\hline C4 & 10.1 & 6.7 \\
\hline C5 & 5.3 & 4.3 \\
\hline Total free-to-air & 85.7 & 62.3 \\
\hline Pay TV Channels of which - & 14.4 & 37.7 \\
\hline Basic & 11.0 & 28.9 \\
\hline Premium, of which & 3.4 & 8.8 \\
\hline Sky Sports 1-3 & 1.8 & 4.8 \\
\hline Total & 100.0 & 100.0 \\
\hline
\end{tabular}

Source: BARB

While pay broadcasters have many sources of supply of basic channels, the supply at the wholesale level of premium sports and movie channels is dominated by BSkyB, which, as well as retailing them directly by satellite, supplies them to broadcasters using rival cable and DTT platforms. These arrangements attracted the attention of the Office of Fair Trading, which in 1996 investigated the price and other conditions of supply (OFT 1996). The Office concluded that BskyB's method of selling its premium channels to its retail competitors had the potential to distort the behaviour of other Pay TV broadcasters, but it found no evidence of broader anti- 
competitive conduct. BSkyB agreed to submit its wholesale rate cards for approval by the Office.

One of the issues investigated by the OFT was the structure of BSkyB's charges for premium channels at both retail and wholesale level. A subscriber who purchased a basic package was then entitled to buy one premium channel at, say, £10 per month. A second could be bought for $£ 6$ per month, a third for $£ 3$ per month and so on. This form of price discrimination, described as "deep discounting", was recognised as having desirable efficiency properties compared with a flat rate structure, given the high fixed and zero marginal costs of providing a channel to a new subscriber. Such pricing does, however, constitute a barrier to entry if one broadcaster gains a monopoly or dominant position in the supply of, say, premium sports programming for which there is no ready substitute.. In such circumstances, deep discounting makes entry difficult for a firm seeking to supply premium movie channels, although the same problem would not apply to an entrant in pay-per-view movies. In the event, the OFT did not find 'deep discounting' by BSkyB to be anti-competitive.

\section{Television Markets in Other European Countries}

The UK pattern of cable or wireless pay TV superimposed upon a strong free-to-air broadcasting system is replicated in other major European countries. As in the UK the wholesale pay TV market is dominated by a single supplier, Canal Plus in France, Telepiu in Italy Canal Plus Espana in Spain and Premiere in Germany, although most of these are subject to some competition. Table 4 summarises the situation for these countries and the UK. 
Table 4

Pay TV Channels in Five European Countries

\begin{tabular}{|l|l|l|}
\hline \multicolumn{1}{|c|}{ Country } & \multicolumn{1}{|c|}{$\begin{array}{c}\text { Delivery } \\
\text { Platforms }\end{array}$} & \multicolumn{1}{|c|}{ Main Competitors } \\
\hline France & Cable, Satellite & Canal Plus, AB Sat, TPS \\
\hline Germany & Cable, Satellite & Premiere \\
\hline Italy & Cable, Satellite & Telepiu, Stream \\
\hline Spain & Cable, Satellite & $\begin{array}{l}\text { Canal Plus, Espana, } \\
\text { Via Digital }\end{array}$ \\
\hline UK & $\begin{array}{l}\text { Cable Satellite, } \\
\text { Digital Terrestrial }\end{array}$ & $\begin{array}{l}\text { Sky, Cable Operatas } \\
\text { On Digital }\end{array}$ \\
\hline
\end{tabular}

Source: Cable and Satellite Europe: various issues

\section{SPORTS RIGHTS - INSTITUTIONAL AND LEGAL CONSIDERATIONS}

\section{The United States}

The importance of broadcast revenues to the major U.S. professional sports leagues may be deduced from two recent estimates displayed in Table 5. Professional football derives more 
than half of its revenues from broadcasting; baseball and basketball about one-third; and hockey much less. The growth in the value of these rights over the past three decades has far outstripped the growth in U.S. economic activity. For example, in 1962 the National Football League signed its first national television contract that paid $\$ 4.7$ million per year. ${ }^{6}$ By 1998 , the NFL's television contracts were yielding them $\$ 2.2$ billion per year, ${ }^{7}$ reflecting a 17 percent nominal annual growth rate. Similar increases were registered by Major League Baseball. However, the greatest growth in national television revenues in recent years has been registered by the NBA, which actually surpassed baseball in 1995. ( See Figure 1.)

Throughout the modern history of sports broadcasting in the U.S., there has always been controversy over the ability of leagues or sports associations to limit individual members' rights to broadcast their games. A new law, the Sports Broadcasting Act, was required in 1961 before sports leagues could offer their rights to national networks in a package. The 1953 U.S. v NFL case invalidated as violation of the Sherman Act a league-wide television contract that limited the ability of individual teams to broadcast their games into other teams' home territories. Later, the same court ruled that a $1960 \mathrm{NFL}$ contract that barred individual teams from selling their games to competing broadcasters was similarly a violation of the Sherman Act.

\footnotetext{
${ }^{6}$ Quirk and Fort (1992), p. 509.

${ }^{7}$ Kagan (1998).
} 
Table 5

Sports Broadcast Rights' Share Total Revenues in U.S. Sports Leagues 1991 and 1997

\begin{tabular}{|l|l|l}
\hline Sport & $\begin{array}{l}1991 \\
\text { Revenue } \\
\text { Share }\end{array}$ & $\begin{array}{l}1997 R e v e \\
\text { nue Share }\end{array}$ \\
\hline Professional Football & 0.60 & 0.56 \\
\hline Major League Baseball & 0.50 & 0.32 \\
\hline Professional Basketball & 0.30 & 0.39 \\
\hline Hockey & & 0.09 \\
\hline
\end{tabular}


Source: Financial World (1991) as quoted in Quirk and Fort (1992);Kagan (1998)

With the passage of the 1961 Act, professional sports leagues were now free to enter into national television contracts that limited broadcasts into teams' territories during the days in which the teams were playing home games. The NFL has had such contracts with national television networks since 1962 that essentially eliminate the teams' own negotiations for local coverage. The revenues from these contracts have been spread evenly across all teams, thereby serving to ameliorate the financial disadvantages of teams in smaller geographical markets ${ }^{8} \mathrm{No}$ other U.S. sports league relies solely on national rights, and none has as large a share of broadcast revenues in total revenues.

The 1961 SBA does not legalize many other forms of restrictive agreements that may be sought by sports leagues in selling broadcast rights. In particular, the courts have invalidated a national broadcasting plan that was devised by the National Collegiate Athletic Association (NCAA) to control the telecasts of all member universities' football games. This plan sharply limited the total number of football games that could be telecast, prohibiting individual teams and leagues from negotiating their own packages. The courts found that were no procompetitive justifications for such sweeping control of college football broadcasts, and it therefore sustained the rights of the two universities to break from the NCAA contracts with $A B C$ and $C B S$ by negotiating their own agreement with a rival network, NBC, in $1982 .{ }^{9}$

In addition, individual teams may still have the ability to sell their broadcast rights even if the league has a national contract. League limitations on a team's right to sell broadcasts of its games to local outlets, regional sports networks, or other broadcasters must be based on a compelling argument that such limitations are required to preserve competition within the league. For example, nearly every basketball, hockey, and baseball team sells broadcast rights to local broadcasters and to regional sports networks. These broadcasts may be

\footnotetext{
${ }^{8}$ This pooling of broadcast revenues does not eliminate the advantages of large-market teams in securing talent, and therefore it does not necessarily contribute to competitive balance. 85,1984

${ }^{9}$ See NCAA v. Board of Regents of the Univ. of Oklahoma \& Univ. of Georgia Athletic Assn, Supreme Court of the United States, 468 U.S
} 
transmitted outside the team's own territory and may even be viewed in a rival team's market. The league may not limit such broadcasts without a sound argument that these broadcasts might undermine the ability of the offended teams to compete in the league. Thus, even sports teams in leagues with national network contracts may sell broadcast rights in games in which the league has no broadcast rights even though such games may dilute the value of the national contract. ${ }^{10}$

The 1992 Cable Act requires cable companies with "attributable" interests in satellitedelivered programming to make such programming available to other distribution technologies on comparable terms. While this provision of the law has been applied only to basic-cable networks thus far, it is quite likely that extensive media ownership of sports teams or leagues could lead to its application to sports programming as well. However, given the limited media ownership of sports teams thus far, such integration is not a major issue in the U.S.

\section{Europe}

UK broadcasters' payments for sports rights are heavily skewed in favour of live soccer rights (see Table 6), and their value has grown over time. (See Table 7). Before 1964 Football League matches were not televised, either in live or highlight form. A Saturday evening highlights program was then introduced. Live broadcasts began in 1983. However, the two broadcasters in a position to bid for the rights (BBC and ITV) acted collusively (Szymanski \& Kuypers 1999, pp 58-9).11 As a result, revenues from broadcast rights remained low until 1992, when Sky Television, the fledgling satellite pay broadcaster, entered the market and won a substantial package of live rights for $£ 37$ million per year, bidding in conjunction with the BBC which maintained a highlights programme on free-to-air television. When the rights were re-auctioned for 1997 - 2001, the annual payment went up fourfold (See Table 7).

${ }^{10}$ See Chicago Profes sional Sports, Ltd. \& WGN v. NBA U.S. Court of Appeals, Seventh Circuit, 961 F. 2d 667, 1992.

\footnotetext{
11 The fact that there was no formal investigation of the duopoly illustrates the lack of interest shown by competition authorities in televised sport.
} 
The dominant role of soccer rights in general and of Premier League rights in particular is shown by the fact that soccer rights in 1997/8 accounted for over three quarters of the annual expenditure on sports rights of BSkyB - the only supplier in the UK of a premium

Table 6

Value of Live Sports Rights in the U.K., 1999

\begin{tabular}{|c|c|c|c|c|}
\hline Sport & Competition & $\begin{array}{c}\text { Broadcaster(s) } \\
\text { F = free } \\
P=\text { pay }\end{array}$ & $\begin{array}{c}\text { Duration } \\
\text { (Yrs) }\end{array}$ & $\begin{array}{c}\text { Annual Charge } \\
(£ \mathrm{~m})\end{array}$ \\
\hline Cricket & Domestic Tests & $\begin{array}{l}\text { BSkyB (P) } \\
\text { C4 (F) }\end{array}$ & 4 & 26 \\
\hline Motorsport & Formula 1 & ITV (F) & 5 & 12 \\
\hline Rugby League & Super League & BSkyB (P) & 5 & 11 \\
\hline Rugby Union & $\begin{array}{l}\text { England } \\
\text { Internationals }\end{array}$ & BSkyB $(P)-$ live & 5 & 18 \\
\hline Snooker & $\begin{array}{l}\text { Embassy World } \\
\text { Championship }\end{array}$ & $\mathrm{BBC}(\mathrm{F})$ & 4 & 10 \\
\hline Soccer & Premier League & BSkyB (P) & 4 & 167 \\
\hline Soccer & Champions League & $\begin{array}{l}\text { On Digital }(P) \\
\text { ITV }(F)\end{array}$ & 3 & 87 \\
\hline Tennis & $\begin{array}{l}\text { Wimbledon } \\
\text { Championships }\end{array}$ & $\mathrm{BBC}$ & 4 & 7 \\
\hline
\end{tabular}

Source: TV Sports Markets

Table 7

The Cost of the Rights to Live Soc cer League Matches

from the Top Division in England,1983 to 2001 


\begin{tabular}{|l|l|l|l|l|l|l|}
\hline & \multicolumn{6}{|c|}{ Start Date of Contract } \\
\hline & $\mathbf{1 9 8 3}$ & $\mathbf{1 9 8 5}$ & $\mathbf{1 9 8 6}$ & $\mathbf{1 9 8 8}$ & $\mathbf{1 9 9 2}$ & $\mathbf{1 9 9 7}$ \\
\hline Length of contract (years) & 2 & 0.5 & 2 & 4 & 5 & 4 \\
\hline Broadcaster & BBC/ITV & BBC & BBC/ITV & ITV & BSkyB & BSkyB \\
\hline Rights fee (£m) & 5.2 & 1.3 & 6.2 & 44 & 191.5 & 670 \\
\hline Annual rights fee (£m) & 2.6 & 2.6 & 3.1 & 11 & 38.3 & 167.5 \\
\hline Number of live matches per season & 10 & 6 & 14 & 18 & 60 & 60 \\
\hline Fees per live match (£m) & 0.26 & 0.43 & 0.22 & 0.61 & 0.64 & 2.79 \\
\hline
\end{tabular}

Source: MMC (1999) para 4.131

sports channel. The popularity of soccer in the UK is shown by the fact that of the most 100 watched free-to-air sports broadcasts in 1998, 77 were of soccer. In the case of pay TV, 96 of 100 were soccer.12

Televised soccer dominates sports programming in other major European countries as well, with similar effects on the value of rights. Thus the winning bids to broadcast the European Champions League from 1999-2002 were as high in France, Germany, Italy and Spain as in the UK. Occasional sporting events, such as the Tour de France, attract audiences in each country, but viewing of soccer dominates.

There are, however, differences among the five European countries in the manner in which rights for the top domestic leagues are sold. In the UK a limited number of games are sold for live broadcast to a single broadcaster (which also makes them available to other platforms) on the basis that no further rights are sold by individual clubs. (This was the subject of a competition law case described below.) In France, the league itself ended this form of exclusivity despite explicit legislative protection. In Spain, clubs sell rights individually. In Italy, the Parliament passed a regulation which prohibits a single broadcaster from controlling more than $70 \%$ of live matches, and the Competition Authority prohibited collective selling by the

12 TV Sports Markets Jan 15, 1999 pp 11-12. 
League of live matches. In Germany, by contrast, the Parliament passed a law which specifically exempted its football league from anti-cartel legislation.

Collective and exclusive agreements in Germany and the UK are still subject tothe provisions of European competition law, and in 1999 the European Commission's Competition Directorate was studying both agreements.

In Europe there is a further specific form of regulation of the sale of rights to sporting events. Under European Union regulation, each member state is entitled to "list" certain sporting or cultural events that the Government believes are of national interest. The holders of rights to such events must first of all offer them to free-to-air broadcasters with universal coverage on fair and reasonable terms. Once this requirement has been satisfied, additional rights may be sold to pay broadcasters. In the UK, for example, the rights in question cover events such as the Olympic Games and Soccer World Cup, and the finals of soccer, rugby and tennis competitions. Elsewhere in Europe, cultural events are 'listed'.

This procedure recognises the fact that sports programming is highly valued by viewers and may also be characterised by a relatively inelastic demand curve, with the consequence that greater revenues can be generated from it by charging directly for it rather than indirectly through the sale of advertising time (see Owen and Wildman, 1992'Listing' is thus motivated by a desire to prevent such "siphoning" of programming.13 This advantage for consumers is, however, gained at the expense of rights holders, who complain that the quality of their sports suffers as a result of being deprived of the true value of the rights.

\section{COMPETITION ISSUES}

The sale of sports broadcast rights raise at least two related competition issues:

14 An FCC examination of siphoning in the US concluded that it was not occurring (FCC 1994). 
(1) Do restrictive agreements among a league's teams reflect a desire to increase the "competitive balance" of the league or are they simply a means to limit competition and reduce sports fans' choices?

(2) Is vertical integration between broadcasters and sports leagues detrimental?

\section{Sports leagues as cartels}

The argument that a sports league is not a cartel relies upon special features of the relationships among its members. In most industries, a fim would benefit from eliminating or weakening its competitors. However, a member of a sports league clearly requires the participation of its competitors to make the competition possible, and, given the evidence that spectators are attracted by competitive balance within a league, 14 , it is not in any team's long term interest unduly to weaken its competitors. Moreover, interest in any league match is based in part upon interest in the competition as a whole. According to this view of the matter, the combination of competitive and co-operative arrangements distinguishes members of a sports league from the members an industrial cartel.

However, it is possible to separate the various activities undertaken by a sports league and its members into those which have to be undertaken collectively to maintain a viable league and those which should be undertaken independently by league members so as to allow the public to benefit from competition.15 Agreement on a set of rules and a centrally coordinated calendar of match dates clearly come into the first category. However, other activities, including the sale of match tickets, are undertaken by clubs individually. Because the sale of broadcast rights falls into the category of activities that each club could undertake separately without harm to the league's ability to offer competitive matches, it is more natural to regard a joint decision by the clubs to restrict output as the operation of a cartel, although the cartel may seek to justify the restriction on public interest grounds.

14 Because uncertainty of the results of any match, or of the competition as a whole, generates spectator interest.

15 A possible analogy is the approach taken in competition law to collaboration among firms in pre -competitive $R$ \& $D$, which may be justified, but is followed by competition in production and selling. 
One argument in favour of a league restriction on the number of broadcast matches is that it enables clubs to avoid diversion of spectators from live games. This can be viewed as action taken by the league to protect another revenue stream. In any case, the evidence on the extent of diversion at current levels of televised matches of Premier League matches in the UK is inconclusive. Tickets to many games are subject to such excess demand that grounds would remain full even if some matches were concurrently televised. (Kuypers 1996)

One of the justifications for league-wide contracts rather than individual-team sales of broadcast rights is that the former provide support to the teams in smaller, less lucrative markets through more or less equal distribution of broadcast revenues. But this does nothing about imbalances in live gates and other forms of revenues.

In any case, Fort and Quirk (1995) have shown that national league -wide contracts do nothing to alter the competitive balance in a league because they do not affect the teams' marginal value of talent. Imbalance occurs when one team-presumably the team in the larger market has a higher marginal value of talent when the talent is equally distributed across teams. As a result, the team from the larger market bids away talent from the others until marginal values of talent are equated - a position attained only when the large market team has more than its proportional share of the talent pool. Since the sharing of national broadcast revenues does not reflect talent shares and, therefore, win-lose percentages, such sharing does not affect the league's competitive balance. This result is not unwelcome to the league that shares broadcast revenues because it is likely to beneft from the maintenance of the competitive imbalance that favors large-market teams.

As Fort and Quirk point out, national broadcast revenues are greater when large-marketteams reach the league championship series because more viewers are interested in the result. Broadcast-revenue sharing implicitly involves a transfer from more successful to less successful teams, but it may nevertheless appeal to the more successful teams. First, if the national contract reduces competition among teams in the sale of broadcast rights, it may increase total broadcast revenues sufficiently to offset the successful team's reduced share of 
revenues. Second, a national contract may keep marginal teams in business, thereby foreclosing an entry opportunity for a second or third league. Thus national contracts may be a form of industry entry barrier.

The U.K.

In a recent case before the UK Restrictive Trade Practices Court, the Director General of Fair Trading argued that the clubs in the Premier League were in effect behaving like a cartel through their decision to sell live broadcast rights to a limited number of their matches ( 60 out of 380 ) to a single broadcaster, on the basis that the remaining matches would be not available for broadcast. In his argument before the Court, the Director General made it plain that he had no objection per se to collective sale of matches by the Premier League. Indeed he suggested that two or more packages of rights could be sold to separate broadcasters, each granting exclusivity over thematches in question, provided thatthis was supplemented by giving the clubs the right to sell further matches on an individual basis. In the Director General's view, this would combine the benefits of giving certain broadcasters a guaranteed package of rights with the availability of further matches for sale to other broadcasters.16 Premier League rights from 2001 are likely to be sold through multiple packages, possibly with limited opportunities for clubs to sell individual matches for delayed broadcasting.

\section{The United States}

In the US, the Sports Broadcast Act opened the door for restrictive, league-wide offerings of broadcasts, but it did not foreclose the option of independent team licensing of some games. The only league that relies solely on national network telecasts of its games is the National Football League. At first, these games were played almost entirely on Sunday afternoons. Thus, the NFL contract would limit choices only during autumn Sundays. Teams could not 
independently license the broadcasts of their home games to local, regional, or other national broadcasters. As the number of networks expanded, the NFL extended its contracts to three and then four networks by broadcasting games on Monday and Thursday nights. Finally, the NFL offered all of its Sunday games to the DTH service, DirecTV. As a result, viewers may now obtain virtually any game from any viewing location on a Sunday afternoon. All NFL broadcast revenues divided evenly among the teams.

Other U.S. leagues employ a mixture ofnational broadcasts, negotiated by the league, and a mix of local and regional broadcasts, negotiated by each team. The result is a less equal distribution of broadcast income and a greater potential for disputes due to overlapping regional broadcasts. The most intense of these disputes involve off-air "superstation" broadcasts, broadcasts by local stations which are retransmitted nationally by satellite.

Ultimately, these superstation broadcasts, involving principally New York, Atlanta, and Chicago basketball, baseball, and hockey teams, are limited through negotiations between the league and the stations"' home teams. The optimal number and mix of broadcasts is difficult to model because no one has ascertained the effect of different broadcast output levels on the competitive balance within leagues or the viewer intensity of demand for sports broadcasts of different teams. As a result, no one knows whether the current mix of broadcasts by local offair stations, off-air networks, regional cable networks, national cable networks, and DTH services is optimal.

Nevertheless, the recent U.S. experience with telecasts of college football is suggestive of the problems with league-wide contracts. Prior to 1984, the National Collegiate Athletic Association (NCAA) negotiated a single national contract for televising football games of major U.S. universities. When two universities attempted to break away from this arrangement and negotiate their own contracts, they were sued by the NCAA. The NCAA lost the suit, ${ }^{17}$

\footnotetext{
16 The Court found that the clubs were not acting as a cartel, and that the form of collective sale employed was not unlawful (Judgment 1999).

${ }^{17}$ National Collegiate Athletic Association v Board of Regents of the University of Oklahoma et al, 468 U.S. 85 (1984).
} 
thereby freeing all member universities to negotiate their own television contracts. The result was a sharp increase in the number of games telecast, a large decline in the value of the television contracts per game, and an increase in competitive balance in college football. ${ }^{18}$

It is unlikely that current television contracts in most U.S. professional leagues involve an important restriction of output. In the first place, most teams now offer a large number of their games through regional cable networks, local broadcast stations, or a combination of the two. Second, major "superstations" export large number of games for the teams from the larger markets to the entire country. Finally, the new broadcast satellites services, particularly DirecTV, offer large packages of games for every major professional sport. A viewer may purchase packages that allows him or her to view virtually any game being played on a given day or night. Thus, in practice, any viewer has access to virtually every major professional sports event in the country, constrained only by occasional invocations of league "black-out" rules.

Were there greater competition among leagues, the prices of these now ubiquitous U.S. telecasts might be lower, but the output of televised sports events would probably not be much greater. National broadcast networks already offer as many as 600 hours per year of sports programming. DirecTV offers as many as 40 professional basketball games per week, 30 professional hockey games per week, and 16 professional football games per week over its national footprint.

\section{Vertical Integration Between Broadcasters and Sports Clubs}

There is a theoretical basis for concluding that vertical integration between broadcasters and sports teams could result in a lessening of competition in the market for sports broadcast rights. The argument that broadcaster ownership of a sports league may be anti-competitive relies in part upon the so called toe-hold effect (Bulow et al 1999). A firm bidding for a

\footnotetext{
${ }^{18}$ Quirk and Fort (1997); Bennett and Fizel (1995).
} 
common value object of which it is already partial owner, will find that its net outlay on purchase will be reduced correspondingly, in relation to the highest unsuccessful bid. This interacts with the 'winner's curse', causing other bidders without a toe hold rationally to reduce their bids for fear that they have over bid in a contest with a competitor which already has an advantage. The operation of this mechanism will thus give a vertically integrated bidder an advantage to the detriment of the owner of the object. This advantage could, however, be substantially reduced by adopting an auction procedure, such as sealed bid tendering, in which the 'winner's curse' plays a less important role.

The U.S.

Media ownership of sports teams is quite limited in the U.S. Indeed, one of the most important early examples of such ownership, the CBS purchase of the New York Yankees baseball club for $\$ 14$ million in 1964, resulted in large losses and an eventual sale at a $\$ 4$ million loss nine years later.

The most important media companies with major professional sports investments are News Corp, Disney, Time-Warner, Comcast, and Cablevision. The Time Warner investments occurred as the result of Time-Warner's purchase of Turner Broadcasting; Ted Turner had owned most of the major sports teams in Atlanta. News Corp recently purchased the Los Angeles Dodgers and options to purchase interests in the Los Angeles Lakers basketball team and the Los Angeles Kings hockey team. Cablevision and Comcast own several sports teams in New York and Philadelphia, respectively. (See Table 8.)

Vertical integration between broadcast media and sports teams is so limited, that its effect on the supply of games broadcast is simply not an issue in the United States. There is simply no evidence on the degree to which broadcasters in New York, Philadelphia, Atlanta, and Los Angeles have used their ownership of sports teams to gain an advantage in bidding for national broadcast rights. Nor is there any evidence that this ownership has 
led to reduction of the amount of programming available in the teams' own geographical market. Since some of these ownership positions for a considerable period of time, particularly in New York and Atlanta, there has been ample time to study such effects, but we are not aware of any attempt to do so.

\section{Europe}

In Europe, there are a limited number of examples of broadcast firms owning sports clubs, especially soccer clubs. The most prominent are the ownership of AC Milan by Mediaset and of Paris St. Germain by Canal Plus. Some restraint on broadcasters' ownership of football clubs is exercised by national and European football association rules, which prevent a single firm from having a controlling stake in two or more clubs playing in the same competition.

Table 8

Media Ownership of U.S. Sports Teams, 1999

\begin{tabular}{|l|l|}
\hline Media Company & U.S. Ownership Interests \\
\hline Comcast Corp. & $\begin{array}{l}\text { Philadelphia 76ers (NBA); Philadelphia Flyers } \\
\text { (NHL); Philadelphia Phantoms (WBA) }\end{array}$ \\
\hline News Corp (Fox) & $\begin{array}{l}\text { Los Angeles Dodgers (MLB); } \\
\text { options to purchase share of Los Angeles } \\
\text { Lakers (NBA) and Los Angeles Kings (NHL) }\end{array}$ \\
\hline & \\
\hline
\end{tabular}




\begin{tabular}{|l|l|}
\hline Walt Disney Co. & $\begin{array}{l}\text { Anaheim Angels (MLB); Mighty Ducks of } \\
\text { Anaheim (NHL) }\end{array}$ \\
\hline Cablevision Systems & $\begin{array}{l}\text { New York Knicks (NBA); New York Rangers } \\
\text { (NHL); New York Liberty (WBA) }\end{array}$ \\
\hline Time Warner, Inc. & $\begin{array}{l}\text { Atlanta Braves (MLB); Atlanta Hawks (NBA; } \\
\text { Atlanta Thrashers (NHL) }\end{array}$ \\
\hline
\end{tabular}

Source: Kagan (1998)

The recent attempted take-over in the UK of Manchester United, the largest and most successful football club, by BSkyB, the monopoly supplier of premium sports programming, was blocked in 1999 following an enquiry by the Monopolies and Mergers Commission. The parties to the proposed merger argued that, whatever position BSkyB occupied in the broadcast market, Manchester United was one of twenty Premier League clubs, with, under current arrangements for the collective sale of broadcast rights, no power of independent action over the pricing of its rights. A vertical merger in which one party exercised no market power would have little incremental impact on competition in either broadcasting or soccer.

The conclusion thus hinged upon questions of market definition: if the broadcast market were broadly defined, to include free-to-air and both basic and pay television, for example, then the acquisition by any broadcaster of a particular set of sports rights would do little to enhance its market power; but if premium pay TV, or premium sports channels represented a separate market, that would be a different matter especially if dominance in that market could be leveraged more widely.

There are difficulties in applying the standard procedures for market definition in application to broadcast markets. Examining the impact of relative price changes is bedeviled by the fact 
that free-to-air television is by definition available at zero financial cost. At the same time, the quality of pay television offerings is likely to vary over time as a result of increases in the number of channels in basic packages and changes in the programming in premium channels.

European competition authorities have addressed this question on several occasions. In 1996, the OFT concluded that the relevant market for the supply of programming at the wholesale level was pay TV in the UK, and that the pay TV market could be further sub-divided into distinct and separable markets for premium sports and movie channels (OFT, 1996). The European Commission's Services have argued that the market seems to be evolving in such a way that it will be no longer possible to define it as for sports programmes in general, but for some specific sports, for example for football or for Formula 1 motor racing (EC, 1998 p.21). In the Premier League case, the Director General of Fair Trading argued that, in the sale of live rights, the economic market was either Premier League matches, or Premier League matches supplemented by other televised matches involving Premier League clubs.19 In the MMC report, the same conclusion was buttressed by:

i) The higher prices per match paid at wholesale level for Premier League matches than for other football matches.

ii) The higher audience figures for Premier League matches or matches involving Premier League teams than for other football matches.

iii) Surveys of pay TV subscribers which suggested that the Premier League and the F.A. Cup were regarded by respondents as the most important football competitions on Sky Sport. (MMC (1999) paras 4.123 - 136.)

At the retail level, the MMC concluded that the relevant market is for pay TV sports premium channels. (Ibid) Paras 4.53 - 121). This analysis underlay the Commission's further conclusion that a higher barrier to entry into premium sports channels would cause the prices

21 The Court did not accept this argument, noting inter alia that the legislation required it to approach market definition in a different way from that conventionally employed by competition authorities. (Judgment 1999) 
for BSkyB's sports channels to be higher than would otherwise be the case. Reduced entry into the sports premium channel market would feed through in to reduced competition in the wider pay TV market. (MMC 1999, para. 2.225). The Commission concluded that a vertically integrated broadcaster would have an advantage in the process, if not from the toe hold effect then from better information about the progress of events. (MMC 1999, para. 2.106 -117). This consideration seems to have played a part, if a limited one, in the Commission's decision to recommend that integration should not be permitted. 20

It is notable that similar concerns havenot been expressed in the United States. The U.S. has one of the most vibrantly competitive video distribution markets in the world. There are now at least six national or quasi-national off-air networks and more than 125 cable networks, approximately 30 regional sports cable networks, as well as two rapidly-growing DTH systems that provide their own sports packages. Several of the national cable networks, such as TNT and USA, provide substantial sports programming while ESPN offers three networks exclusively devoted to sports.

There is simply no evidence that entry into the video distribution market has been constrained by the absence of sports license agreements from major sports leagues. Indeed, DirecTV's ability to obtain rights to all of the major sports leagues"' games suggests that these leagues fear antitrust prosecution, federal regulation, or the threat of entry by new leagues if they deny new distribution media their broadcast rights.

\section{CONCLUSIONS}

It is clear from the foregoing that there are significant differences between the United States and the major European countries, both in the organisation of sporting events which generate sports rights, and in the organisation of the retail market for sports

20 Since the prohibition of the take-over of Manchester United, BSkyB and two other UK broadcasters have brought stakes of less than $10 \%$ in eight Premier League Clubs. These have the same 'toe-hold' effects. 
programming. In particular:

1. In the United States, interest in sports on the part of the public, either as spectators at sporting events or as viewers of sports broadcasts, is much more balanced across sports than in France, Germany, Italy, Spain and the UK where soccer plays a pre-eminent role.;

2. In the United States, the broadcast market, especially the pay-broadcast market, has not exhibited the dominance by one or a small number of firms which has characterised the development of pay-broadcasting in the major European countries.

Each of these points reflects in part the much larger size of the market in the United States. We have argued above that in Europe a combination of skewed consumer tastes for soccer and of limited opportunities for entry into the broadcasting market on the back of other sports has created a situation in which rights holders can, through collective selling, exploit a dominant or monopoly position in the rights markets and - if they choose to - can leverage that market power in broadcasting.

The problem is exacerbated by significant political influence wielded both in the upstream market where the sports rights are generated and in the down stream market where sports and other rights are packaged and sold by broadcasters. In the former case, this is demonstrated by the success of legislation in both the United States and Germany which has exempted sporting organisations from certain provisions of national competition law. In the latter case, governments are often reluctant to antagonise broadcasters who may wield significant political influence.

Concentration of ownership of sports rights thus can become the source of significant competition problems. US and European experience suggests that collective sale of rights by 
a sports body is not inherently objectionable, but only becomes so when combined with exclusivity - the sale of a limited number of matches to a single broadcaster, and further sale being prohibited.

In the US, the professional sports league that sells all of its matches to national broadcasters, the NFL, hasdemonstrated a preference for doing so to a variety of competing broadcasters. In several European countries, a collective contract does not prevent clubs from selling individual matches to other broadcasters. The English and German soccer leagues, by contrast, have sold through collective and exclusive contracts which run the risk of leveraging dominant positions in pay broadcasting. Such deals are likely to be anti-competitive and against the public interest in almost all circumstances, when they apply to leagues dominant in their markets.

European experience suggests that, because of the strength of vested interests, competition authorities are the only bodies likely to be prepared to intervene to protect consumers of broadcast services. For this reason, their vigilance in the scrutiny of collective selling agreements is clearly warranted. In order to carry out this function, they need to devote considerable attention to market definition at wholesale and retail levels, and to have a full understanding of the complexities of the broadcasting market, arising from the co-existence of services financed in quite different ways. 


\section{References}

Bennett, Randall W. and John L. Fizel (1995), "Telecast Deregulation and Competitive Balance: Regarding NCAA Division I Football," American Journal of Economics and Sociology, Vol. 54, pp. 183-199.

Bulow, J, M Huang and P Klemperer (1999), "Toe Holds and Takeovers", Journal of Political Economy. Vol. 107 No 3 pp 427-454.

Competition Commission (2000), NTL Incorporated and Cable and Wireless Communications Plc. $\mathrm{Cm} 4666$

Deloitte \& Touche (1999), England's Premier Clubs : A Review of 1998 Results.

European Commission (1998) "Broadcasting of Sports Events and Competition Law: An Orientation Documents from the Commission Services", Competition Policy NewsletterNo. 2, June. Pages $18-29$.

FCC (1994), Inquiry into Sports Programming Migration Final Report PP Docket 93-21. June.

Fort, Rodney and James Quirk (1995), "Cross Subsidization, Incentives, and Outcomes in Professional Team Sports Leagues," Journal of Economic Literature, Vol. XXXIII, September, pp. 1265-99.

(1997), "Introducing a Competitive Economic Environment into Professional Sports," in Wallace Hendricks, (ed.), Advances in the Economics of Sport, Vol. 2,. London: JAI Press.

Hoehn, T and S Szymanski. (1999), “The Americanisation of European Football” Economic 
Policy No. 28 pp 205-240.

Horowitz, Ira (1974), "Sports Broadcasting" in Roger G. Noll, ed., Government and the Sports Business. The Brookings Institution.

Kagan, Paul (1998), Kagan's Media Sports Business Databook. Carmel, CA.

Kuypers, T.J. (1999), The Beautiful Game? An Econometric Study of Why People Watch English Football Discussion Papers in Economics, University College London 96-101.

Monoply and Mergers Commission (1999), British Sky Broadcasting Group Plc and Manchester United Plc: A Report on the Proposed Merger. Competition Commission, Cm 4305.

Office of Fair Trading (1996), The Director General's Review of BSkyB's Position In The Wholesale Pay TV Market.

Owen, Bruce and Steven S. Wildman ( 1992), Video Economics. Harvard University Press.

Quirk, James and Rodney D. Fort (1992), Pay Dirt: The Business of Professional Team Sports. Princeton University Press.

Scully, Gerald W. (1995), The Market Structure of Sports. University of Chicago Press.

Sheehan, Richard G., 1996, Keeping Score: The Economics of Big-Time Sports. Diamond Communications, Inc.

Szymanski, Stefan and Tim Kuypers (1999), Winners and Losers : the Business Strategy of Football, Viking.

Weiler, Paul C. and Gary R. Roberts (1993), Sports and the Law: Text, Cases, Problems. Second Edition, West Group. 
